\title{
Origin and fate of particulate and dissolved organic matter in a naturally iron-fertilized region of the Southern Ocean
}

\author{
L. Tremblay ${ }^{1}$, J. Caparros ${ }^{2,3}$, K. Leblanc ${ }^{4}$, and I. Obernosterer ${ }^{2,3}$ \\ ${ }^{1}$ Department of Chemistry and Biochemistry, Université de Moncton, Moncton, NB, E1A 3E9, Canada \\ ${ }^{2}$ CNRS, UMR 7621, Laboratoire d'Océanographie Microbienne, Observatoire Océanologique, 66650 Banyuls/mer, France \\ ${ }^{3}$ Sorbonne Universités, UPMC Univ Paris 06, UMR 7621, Laboratoire d'Océanographie Microbienne, \\ Observatoire Océanologique, 66650 Banyuls/mer, France \\ ${ }^{4}$ Aix Marseille Université, CNRS, Université de Toulon, IRD, Mediterranean Institute of Oceanography (MIO), UM 110, \\ 13288, Marseille, France
}

Correspondence to: L. Tremblay (luc.tremblay@umoncton.ca)

Received: 3 September 2014 - Published in Biogeosciences Discuss.: 2 October 2014

Revised: 9 December 2014 - Accepted: 11 December 2014 - Published: 30 January 2015

\begin{abstract}
Natural iron fertilization of high-nutrient lowchlorophyll (HNLC) waters induces annually occurring spring phytoplankton blooms off the Kerguelen Islands (Southern Ocean). To examine the origin and fate of particulate and dissolved organic matter (POM and DOM), D- and L-amino acids (AA) were quantified at bloom and HNLC stations. Total hydrolyzable AA accounted for $21-25 \%$ of surface particulate organic carbon $\left(\% \mathrm{POC}_{\mathrm{AA}}\right)$ at the bloom sites, but for $10 \%$ at the HNLC site. A marked decrease in $\% \mathrm{POC}_{\mathrm{AA}}$ with depth was observed at the most productive stations leading to values between 3 and $5 \%$ below $300 \mathrm{~m}$ depth. AA contributed to only $0.9-4.4 \%$ of dissolved organic carbon $\left(\% \mathrm{DOC}_{\mathrm{AA}}\right)$ at all stations. The only consistent vertical trend was observed at the most productive station (A3-2) where $\% \mathrm{DOC}_{\mathrm{AA}}$ decreased from $\sim 2 \%$ in the surface waters to $0.9 \%$ near $300 \mathrm{~m}$. These AA yields revealed that POM and DOM were more rapidly altered or mineralized at the bloom sites compared to the HNLC site. Alteration state was also assessed by trends in $\mathrm{C} / \mathrm{N}$ ratio, \% D-AA and degradation index. Different molecular markers indicated that POM mostly originated from diatoms and bacteria. The estimated average proportion of POM from intact phytoplankton cells in surface waters was $45 \%$ at the bloom station A3-2, but $14 \%$ at the HNLC site. Estimates based on D-AA yields indicated that $\sim 15 \%$ of POM and $\sim 30 \%$ of DOM was of bacterial origin (cells and cell fragments) at all stations. Surprisingly, the DOM in HNLC waters appeared less altered than the DOM from the bloom, had slightly higher dissolved AA
\end{abstract}

concentrations, and showed no sign of alteration within the water column. Unfavorable conditions for bacterial degradation in HNLC regions can explain these findings. In contrast, large inputs of labile organic molecules and iron likely stimulate the degradation of organic matter (priming effect) and the production of more recalcitrant DOM (microbial carbon pump) during iron-fertilized blooms.

\section{Introduction}

The Southern Ocean plays a key role in the global carbon cycle because it represents an important physical and biological $\mathrm{CO}_{2}$ sink (Le Quéré et al., 2007). The magnitude of the biological contribution to the $\mathrm{CO}_{2}$ sink is driven by primary productivity and the fate of the organic matter (OM) produced. It was univocally shown that iron controls primary production in the Southern Ocean having the largest high-nutrient lowchlorophyll (HNLC) zone (Boyd et al., 2007). The extent to which biological degradation of particulate (POM) and dissolved organic matter (DOM) affect their potential export to depth and preservation is far from understood (Ebersbach and Trull, 2008).

Natural iron fertilization induces intense phytoplankton blooms in spring, especially around the Kerguelen Islands (Blain et al., 2007). Blooms induced by natural iron fertilization likely represent major events for heterotrophic bacteria which are reported to be limited by carbon in the HNLC 
Southern Ocean (Church et al., 2000). Indeed, pronounced responses of heterotrophic bacteria are reported from natural iron-fertilization studies (Zubkov et al., 2007; Christaki et al., 2008, 2014). Rapid bacterial mineralization of 45\% of the primary production was observed during the decline of the spring phytoplankton bloom above the Kerguelen Plateau (Obernosterer et al., 2008). Furthermore, the efficiency of the carbon export, defined as the ratio of particulate organic carbon (POC) in deep waters to primary production, was about 2 times lower above the Kerguelen Plateau than in HNLC waters (Savoye et al., 2008). These findings suggest that the POM produced during the bloom is relatively labile, and rapidly turned over. Although DOM production is an essential step during bacterial mineralization, the effect of iron fertilization on the concentration and reactivity of DOM has been far less studied.

To better understand to role of the Southern Ocean in the cycles of carbon and other vital elements, such as nitrogen, it is important to study the origin and fate of its $\mathrm{OM}$ in regions having contrasting conditions and productivities. To do so, molecular level analyses of POM and DOM provide unique and valuable pieces of information. Amino acid enantiomers (L- and D-AA) are among the few markers that can be analyzed in bulk seawater at ambient concentrations and provide numerous indicators on OM origin and fate (e.g., Kaiser and Benner, 2008; Dittmar et al., 2009). AA contain most of the nitrogen in living organisms and are important constituents of detrital POM and DOM (Cowie and Hedges, 1992). While L-AA are ubiquitous (e.g., all proteins), DAA are only produced in important proportions in bacteria (Asano and Lübbehüsen, 2000).

AA are generally selectively utilized by heterotrophic organisms compared to bulk OM. As a result, the proportions of bulk carbon and nitrogen in the form of AA, or AA yields, decrease with time and are useful indicators of POM and DOM alteration state (Cowie and Hedges, 1994; Davis et al., 2009). Other independent diagenetic markers are the molar percentage (mol\%) of D-AA versus total hydrolyzable AA (THAA) (Tremblay and Benner, 2009) and the degradation index (DI) calculated based on the relative distribution of individual AA (Dauwe et al., 1999; Peter et al., 2012). An increase in mol\% D-AA during degradation is attributed to the bacterial contribution of D-AA to the OM and to a lower degradation rate of the bacterial biomolecules rich in D-AA compared to proteins having only L-AA (Nagata et al., 2003). During degradation some AA are selectively degraded (the others are selectively preserved) and these changes reduce the DI value. AA yields are known to be more sensitive to the first alterations of the OM compared to mol\% D-AA and DI which require more intense alterations before showing consistent changes (Davis et al., 2009; Bourgoin and Tremblay, 2010).

C- and N-normalized yields of individual D-AA (e.g., Dalanine) were shown to have a similar dynamic as bulk bacterial C and N, respectively (Tremblay and Benner, 2006;
Kaiser and Benner, 2008). Thus, these yields can be used to estimate the contribution of bacteria (from intact cells and cell fragments or detritus) to POM and DOM. The description of this approach and its limitations are presented in previous studies (Tremblay and Benner, 2006, 2009; Kaiser and Benner, 2008; Kawasaki et al., 2011). In addition, plots of the sum of serine and threonine versus the ratio aspartic acid / glycine have been previously utilized to discriminate different carbon sources, specifically diatoms, coccolithophores and bacteria (Ittekkot et al., 1984; Gupta and Kawahata, 2000; Salter et al., 2010).

The objective of this work was to evaluate the origin and fate of the OM produced during spring phytoplankton blooms in the naturally iron-fertilized Southern Ocean. To do so, bulk and AA enantiomeric analyses were done on unfiltered and filtered waters collected at different bloom sites and in HNLC waters during the KEOPS2 (Kerguelen Ocean and Plateau compared Study 2) expedition. This work provides a detailed description of OM characteristics and new evidences on the distinct fates of the OM from naturally iron-fertilized regions.

\section{Materials and methods}

\subsection{Site description and sampling}

Among the sampling sites visited during the KEOPS2 campaign in October and November 2011, five stations were selected for the present study (Table 1) (map available in Blain et al., 2014). Station R-2 (bottom depth $=2532 \mathrm{~m}$ ) was located in a HNLC region outside the western boundary of the Kerguelen Plateau. In contrast, station A3-2 (bottom depth $=527 \mathrm{~m}$ ) was in the center of the phytoplankton bloom that occurs annually above the Kerguelen Plateau. Stations E1 (bottom depth $=2056 \mathrm{~m}$ ) and E-5 (bottom depth $=1920 \mathrm{~m}$ ) were located in offshore waters within a stationary meander south of the polar front and these stations were sampled in a quasi-Lagrangian manner before (E-1) and during the bloom (E-5). TEW-2 is a shallow station (total depth $=85 \mathrm{~m}$ ) above the eastern continental shelf of Kerguelen Island and it is characterized by continental inputs and relatively high productivity. Sampling depths were selected to cover important features of water masses revealed by CTD (conductance, temperature, depth) profiling. The surface mixed layer depth was $105 \mathrm{~m}$ at station R-2, $153 \mathrm{~m}$ at station A3-2, $46 \mathrm{~m}$ at station E-5, $72 \mathrm{~m}$ at station E-1, and $40 \mathrm{~m}$ at station TEW-2. Because of water quantity and time limitations, only the first $350 \mathrm{~m}$ of the water column were sampled at E-5.

Water samples for AA, dissolved organic carbon (DOC) and nitrogen (DON) analyses were collected using $10 \mathrm{~L}$ Teflon-lined Niskin-1010X bottles mounted on a 1018 rosette system adapted for trace metal clean work (Bowie et al., 2014). Subsamples were transferred to $500 \mathrm{~mL}$ Schott glass bottles that were rinsed with acid $(\mathrm{HCl}, 10 \%)$ and then ultrapure water before use. Part of each water sample 
Table 1. Sampling sites, chlorophyll $a(\mathrm{Chl} a)$ concentrations, particulate and dissolved organic carbon (POC, DOC) and nitrogen (PON, DON) concentrations, and amino acid (AA) concentrations in particulate and dissolved (including free AA) phases.

\begin{tabular}{|c|c|c|c|c|c|c|c|c|c|c|c|c|}
\hline \multirow[t]{2}{*}{ Stations } & \multicolumn{2}{|c|}{ Coordinates } & \multirow{2}{*}{$\begin{array}{c}\text { Depth } \\
\text { (m) }\end{array}$} & \multirow{2}{*}{$\begin{array}{c}{[\mathrm{Chl} a]} \\
\left(\mu \mathrm{gL}^{-1}\right)^{\mathrm{a}}\end{array}$} & \multirow{2}{*}{$\begin{array}{l}{[\mathrm{POC}]} \\
(\mu \mathrm{M})^{\mathrm{a}}\end{array}$} & \multirow{2}{*}{$\begin{array}{c}\text { [DOC] } \\
(\mu \mathrm{M})\end{array}$} & \multirow{2}{*}{$\begin{array}{l}{[\mathrm{PON}]} \\
(\mu \mathrm{M})^{\mathrm{a}}\end{array}$} & \multirow{2}{*}{$\begin{array}{l}{[\mathrm{DON}]} \\
(\mu \mathrm{M})^{\mathrm{b}}\end{array}$} & \multicolumn{3}{|c|}{$\begin{array}{l}{[\mathrm{AA}]} \\
(\mathrm{nM})\end{array}$} & \multirow{2}{*}{$\begin{array}{l}\text { Free } \mathrm{AA}^{\mathrm{e}} \\
\quad(\%)\end{array}$} \\
\hline & $\begin{array}{l}\text { Latitude } \\
{ }^{\circ} \mathrm{S}\end{array}$ & $\begin{array}{l}\text { Longitude } \\
{ }^{\circ} \mathrm{E}\end{array}$ & & & & & & & partic. ${ }^{\mathrm{c}}$ & dissolv. $^{\mathrm{d}}$ & free & \\
\hline \multirow{8}{*}{$\begin{array}{l}\text { R-2 }(\text { HNLC) })^{\mathrm{f}} \\
27 \text { Oct } 2011^{\mathrm{g}}\end{array}$} & 50.383 & 66.683 & 40 & 0.32 & 7.8 & 48 & 0.8 & 6.0 & 162 & 335 & 38 & 11.3 \\
\hline & & & 70 & 0.27 & nd & 47 & nd & 6.1 & 262 & 216 & nd & \\
\hline & & & 100 & 0.23 & 5.2 & 48 & 0.7 & 6.9 & 498 & 276 & nd & \\
\hline & & & 200 & 0.02 & 2.9 & 47 & 0.3 & nd & 45 & 173 & nd & \\
\hline & & & 300 & nd & nd & 45 & nd & nd & 23 & 198 & nd & \\
\hline & & & 500 & nd & 1.5 & 44 & 0.1 & nd & 77 & 186 & nd & \\
\hline & & & 900 & nd & 1.6 & 45 & 0.1 & nd & 92 & 192 & 11 & 5.7 \\
\hline & & & 1300 & nd & nd & 44 & nd & nd & 33 & 151 & nd & \\
\hline \multirow{6}{*}{$\begin{array}{l}\text { A3-2 } \\
17 \text { Nov } 2011^{\mathrm{g}}\end{array}$} & 50.617 & 72.050 & 40 & 1.7 & 14.8 & 52 & 2.8 & 6.0 & 821 & 277 & 52 & 18.8 \\
\hline & & & 70 & 2.1 & 14.3 & 51 & 2.6 & 5.1 & 716 & 292 & 69 & 23.6 \\
\hline & & & 110 & 2.4 & 13.9 & 50 & 2.6 & 3.9 & 656 & 237 & nd & \\
\hline & & & 150 & 1.4 & 10.8 & 48 & 2.1 & 5.3 & 400 & 173 & nd & \\
\hline & & & 210 & 0.15 & 3.5 & 47 & 0.4 & 3.9 & 44 & 144 & 10 & 6.9 \\
\hline & & & 300 & 0.05 & 2.0 & 48 & 0.3 & 2.7 & 22 & 128 & nd & \\
\hline \multirow{5}{*}{$\begin{array}{l}\text { E-5 } \\
18 \text { Nov } 2011^{\mathrm{g}}\end{array}$} & 48.400 & 71.884 & 25 & 1.2 & 11.0 & 48 & 2.2 & 6.5 & 539 & 208 & 28 & 13.5 \\
\hline & & & 70 & 0.95 & 9.1 & 47 & 2.2 & 7.0 & 333 & 234 & nd & \\
\hline & & & 110 & 0.36 & nd & 47 & 0.6 & 6.8 & 71 & 160 & nd & \\
\hline & & & 200 & 0.12 & 3.5 & 46 & 0.3 & 6.9 & 45 & 191 & 6 & 3.1 \\
\hline & & & 350 & nd & 3.0 & 45 & 0.2 & nd & 27 & 146 & nd & \\
\hline \multirow{7}{*}{$\begin{array}{l}\text { E-1 } \\
30 \text { Oct } 2011^{\mathrm{g}}\end{array}$} & 48.450 & 72.183 & 20 & 0.99 & 7.7 & 49 & 1.3 & 4.8 & 223 & 406 & nd & \\
\hline & & & 40 & 0.96 & 8.9 & 49 & 1.6 & 5.0 & 486 & 352 & nd & \\
\hline & & & 70 & 0.86 & 4.5 & 47 & 1.0 & 5.2 & 124 & 495 & nd & \\
\hline & & & 120 & 0.78 & 6.5 & 46 & 1.2 & 6.4 & 387 & 289 & nd & \\
\hline & & & 200 & 0.07 & 5.1 & 45 & 1.0 & nd & 203 & 314 & nd & \\
\hline & & & 500 & nd & 1.6 & 45 & 0.1 & nd & nd & 383 & nd & \\
\hline & & & 1300 & nd & nd & 45 & nd & nd & 44 & 199 & nd & \\
\hline \multirow{3}{*}{$\begin{array}{l}\text { TEW-2 (shelf) } \\
31 \text { Oct } 2011^{\mathrm{g}}\end{array}$} & 48.884 & 70.650 & 15 & 1.8 & 9.3 & 47 & 1.5 & 7.4 & 627 & 413 & 37 & 9.0 \\
\hline & & & 30 & 1.4 & 5.7 & 46 & 1.0 & 7.1 & 338 & 489 & nd & \\
\hline & & & 62 & 0.6 & 6.4 & 45 & 0.7 & 7.6 & 205 & 403 & 11 & 2.7 \\
\hline \multicolumn{13}{|c|}{$\begin{array}{l}\text { a Data are from Lasbleiz et al. (2014). } \\
\text { b Data are from Blain et al. (2014). } \\
\text { c Particulate AA = total hydrolyzable amino acids (THAA). } \\
\text { d Dissolved AA = dissolved combined and free amino acids. } \\
\text { e \% free amino acids versus dissolved AA. } \\
{ }^{\mathrm{f}} \text { High-nutrient low-chlorophyll. } \\
\mathrm{g} \text { Dates of sampling. } \\
\text { nd: not determined. }\end{array}$} \\
\hline
\end{tabular}

was filtered through two combusted GF/F filters (glass fiber, $0.7 \mu \mathrm{m}$ nominal pore size, Whatman) using a Hamilton glass syringe and PTFE (polytetrafluoroethylene) tubing. For AA analyses of the dissolved fraction, $20 \mathrm{~mL}$ of the GF/F filtered water were stored in HDPE (high-density polyethylene) bottles at $-20^{\circ} \mathrm{C}$. For DOC analyses, $15 \mathrm{~mL}$ of the $\mathrm{GF} / \mathrm{F}$ filtered water were acidified $\left(\mathrm{H}_{3} \mathrm{PO}_{4}\right.$, final $\left.\mathrm{pH}=2\right)$ and stored in the dark in combusted and sealed glass ampoules. DON analyses were done with an aliquot of the $\mathrm{GF} / \mathrm{F}$ filtered water that was stored poisoned $\left(100 \mu \mathrm{L}\right.$ of $\mathrm{HgCl}_{2} ; 4 \mathrm{gL}^{-1}$, working solution) in PTFE bottles (Blain et al., 2014). Total AA (dissolved and particulate) were determined in $20 \mathrm{~mL}$ of unfiltered water stored in HDPE bottles at $-20^{\circ} \mathrm{C}$. The concentration of particulate AA was calculated by subtracting the
AA concentration in filtered water from the total AA concentration.

Water samples for POC and PON analyses were collected with regular $12 \mathrm{~L}$ Niskin bottles. A total of $1 \mathrm{~L}$ of seawater was filtered on combusted GF/F filters, and these were stored in the dark until analyses (Lasbleiz et al., 2014). The sampling depths of these water samples did not always perfectly match the depths of the samples used for the other analyses. In these cases, the depths that were the closest to those shown on Table 1 were used for POC and PON. 


\subsection{Organic carbon and nitrogen analysis}

DOC concentrations were measured on acidified aliquots using a Shimadzu TOC-VCP analyzer with a Pt catalyst at $680^{\circ} \mathrm{C}$ (Benner and Strom, 1993). All DOC analyses were run in duplicate and 3-5 injections were done for each sample. Analytical precision was $0.2-1 \%(\mathrm{CV})$. Reference materials (http://www.rsmas.miami.edu/groups/ biogeochem/CRM.html) were injected every 15 samples to insure stable operating conditions. DON concentrations were determined after wet oxidation and calculated as the difference between total $\mathrm{N}$ concentration and the sum of inorganic $\mathrm{N}$ (i.e., nitrate, nitrite, ammonium) (Blain et al., 2014). Inorganic $\mathrm{N}$ was determined by the automated colorimetric technique on a Skalar autoanalyzer (Aminot et Kérouel, 2007). POC and PON analyses of particles on filters were done on a PerkinElmer 2400 CHN analyzer (Lasbleiz et al., 2014). The filter blank values for POC and PON corresponded to $1.27 \mu \mathrm{M} \pm 0.26$ and $0.06 \mu \mathrm{M} \pm 0.02$, respectively.

\subsection{Amino acid analysis}

AA enantiomers ( $\mathrm{L}$ and $\mathrm{D}$ ) and achiral AA were measured after liquid-phase acid hydrolysis and reversed-phase highperformance liquid chromatography (HPLC) according to a newly developed procedure (Escoubeyrou and Tremblay, 2014). This procedure is similar to traditional ones, except that a high volume $(100 \mu \mathrm{L})$ of undiluted samples is injected and a robust hybrid C-18 column is used. These changes increase the precision of the measurements while providing a more consistent separation.

Briefly, $366 \mu \mathrm{L}$ of seawater (filtered or unfiltered) were transferred to an ampoule and mixed with $634 \mu \mathrm{L}$ of $\mathrm{HCl}$ $30 \%$ (Merck, Suprapur grade). Procedural blanks were also prepared with $634 \mu \mathrm{L}$ of $\mathrm{HCl} 30 \%$. The ampoules were then vacuum sealed and placed at $110^{\circ} \mathrm{C}$ for $20 \mathrm{~h}$. After hydrolysis, $300 \mu \mathrm{L}$ of hydrolyzate ( $190 \mu \mathrm{L}$ for blanks) were evaporated on a Genevac Personal Evaporator (EZ-2 + HCl compatible). A total of $150 \mu \mathrm{L}$ of ultrapure water were then added and evaporated to remove remaining traces of $\mathrm{HCl}$. Samples consisting of $110 \mu \mathrm{L}$ of nonhydrolyzed seawater were also evaporated for the analysis of free AA. Samples and blanks were then dissolved in $120 \mu \mathrm{L}$ of borate buffer $(0.4 \mathrm{M}$, Merck, Suprapur) with a pH adjusted to 10 with $\mathrm{NaOH} 6 \mathrm{M}$ (Merck, Suprapur). Strong vortex agitation and sonication were necessary to completely dissolve the dried residue. The vials were then centrifuged ( $4300 \mathrm{rpm}, 5 \mathrm{~min}$ ) to separate the flocculate formed in borate buffer.

HPLC analyses were performed on an Ultimate 3000 Dionex system equipped with an autosampler and a fluorescence detector (excitation at $335 \mathrm{~nm}$, emission at $450 \mathrm{~nm}$ ). The separation was done with a Phenomenex Gemini C18 column $(250 \times 4.6 \mathrm{~mm}, 5 \mu \mathrm{m}, 110 \AA)$ and a SecurityGuard column $(4 \times 3 \mathrm{~mm})$. Automated precolumn derivatization with o-phthaldialdehyde (OPA) and N-isobutyryl-L-cysteine
(IBLC, L-run) or with OPA and N-isobutyryl-D-cysteine (IBDC, D-run) was performed. The reagents were prepared by dissolving $2 \mathrm{mg}$ of OPA and $5 \mathrm{mg}$ of IBLC or IBDC in $200 \mu \mathrm{L}$ of methanol and diluting with $1.8 \mathrm{~mL}$ of ultrapure water. The derivatization mixture consisted of $100 \mu \mathrm{L}$ of sample or blank, $10 \mu \mathrm{L}$ of OPA/IBD(L)C reagent and $10 \mu \mathrm{L}$ of S-methyl-L-cysteine (SMC, $0.74 \mu \mathrm{M})$ used as internal standard. After a reaction time of $2 \mathrm{~min}$ at $8^{\circ} \mathrm{C}, 100 \mu \mathrm{L}$ of this mixture were injected. OPA/IBLC (run L) and OPA/IBDC (run D) were used alternatively for every sample and blank. The elution order of L-AA and D-AA is reversed during the second run, which increases the accuracy of peak identification and quantification (Brückner et al., 1994). The largest peak of the two runs was not considered because it may be caused by a coelution. The column temperature was maintained at $44{ }^{\circ} \mathrm{C}$. A gradient of organic phase $(93 \%$ methanol, $7 \%$ acetonitrile) and $\mathrm{KH}_{2} \mathrm{PO}_{4}$ aqueous solution $(40 \mathrm{mM}, \mathrm{pH}$ 6.15 ) was used with a flow rate of $0.8 \mathrm{~mL} \mathrm{~min}^{-1}$ (Escoubeyrou and Tremblay, 2014).

Before injecting samples, blanks or standards, several analyses of borate buffer were performed to check the level of contamination from free AA. AA identification and quantification in unknown samples and blanks were achieved by comparing the retention times and peak areas with those of standard AA solutions. Coefficients of determination of calibration curves were always between 0.99 and 1.0. Standard solutions contained 23 AA: L- and D-aspartic acid (L/DAsp), L- and D-glutamic acid (L/D-Glu), L- and D-serine (L/D-Ser), L- and D-alanine (L/D-Ala), L- and D-valine (L/D-Val), L- and D-leucine (L/D-Leu), L-threonine (L-Thr), glycine (Gly), L-arginine (L-Arg), L-isoleucine (L-Ileu), Lphenylalanine (L-Phe), L-lysine (L-Lys), L-histidine (L-His), L-tyrosine (L-Tyr), L-methionine (L-Met), $\gamma$-aminobutyric acid (Gaba), and $\beta$-alanine (BAla).

Peak areas of AA measured in blanks were subtracted from those in samples. The borate buffer solution was used as the blank for the quantification of free AA. Individual AA concentrations in injected samples were then calculated using the slope of calibration curve of each AA. The average racemization rates of individual free and protein AA occurring during hydrolysis and measured by Kaiser and Benner (2005) were used to correct the concentrations of chiral AA. Asp and Glu peaks included the contribution of Lglutamine (Gln) and L-asparagine (Asn), respectively, which were deaminated during hydrolysis. They were thus identified as Asx and Glx.

Particulate THAA were quantified by the difference between the peak areas obtained with unfiltered and filtered hydrolyzed samples. The chromatograms of filtered samples were used to quantify dissolved AA, which are the sum of free and dissolved combined AA. Dissolved combined THAA can be determined by the difference between the peak areas obtained with filtered hydrolyzed and nonhydrolyzed samples. The limits of detection were $0.007-3.57 \mathrm{nM}$ depending on the AA (Escoubeyrou and Tremblay, 2014). Most 
particulate AA (determined by difference) were near their limit of detection in samples having low POC concentrations. This increases the uncertainty of particulate AA, POC and PON values in these samples.

\subsection{Chlorophyll analysis}

Concentrations of chlorophyll $a$ were determined by HPLC following the protocol of Van Heukelem and Thomas (2001) modified by Ras et al. (2008). Seawater samples (1-2.23 L) were filtered on $25 \mathrm{~mm} \mathrm{GF/F}$ filters (Whatman) which were then stored in cryotubes in liquid nitrogen until further processing in the home lab, as described in detail in Lasbleiz et al. (2014).

\section{Results}

\subsection{Organic carbon and nitrogen}

Striking differences in OM concentrations and compositions were observed between stations (Table 1). As expected, station R-2 located in the HNLC region exhibited the lowest chlorophyll $a\left(<0.32 \mu \mathrm{gL}^{-1}\right)$ and POC concentrations $(1.5-7.8 \mu \mathrm{M})$ compared to the other stations for similar depths. The highest concentrations of chlorophyll $a$ (up to $2.4 \mu \mathrm{g} \mathrm{L}^{-1}$ ) and POC (up to $14.8 \mu \mathrm{M}$ ) were observed in the mixed layer at station A3-2. Station E-1, sampled before the bloom, had relatively low POC concentrations in its surface waters $(7.7 \mu \mathrm{M}$ at $20 \mathrm{~m})$. After 19 days, the POC concentrations increased to $11 \mu \mathrm{M}$ at E-5. There was a marked decrease in POC concentrations with depth, especially at station A32 showing a 7.4-fold decrease. The lowest POC concentrations, $1.5-3 \mu \mathrm{M}$, were measured below $210 \mathrm{~m}$.

DOC represented 78 (surface water of A3-2)-97\% (deep water of R-2) of total organic carbon (Table 1). Despite a slight decreasing trend with depth at all stations, DOC concentrations were much less variable than those of POC. The highest concentrations $(51-52 \mu \mathrm{M})$ were measured in the surface waters of station A3-2, the bloom site above the plateau. The lowest concentration $(44 \mu \mathrm{M})$ was found in the deep waters of the less-productive station R-2.

PON and DON concentrations also varied with location and depth (Table 1). They generally followed the same trends as their carbon counterparts, although not always to the same extent as indicated by the POC / PON and DOC / DON ratios in representative samples (Fig. 1). A preferential degradation of N-rich molecules in particles lead to a general increase in POC / PON ratios with depth (Fig. 1a). As expected, the particles in the surface waters of the bloom at stations A3-2 and E-5 were enriched in N. In contrast, the HNLC region (station R-2) had more N-poor particles (Fig. 1a) and 2-3.5 times lower PON concentrations (Table 1). DON concentrations varied from $7.6 \mu \mathrm{M}$ at station TEW-2 to $2.7 \mu \mathrm{M}$ in the deep waters of station A3-2. Station A3-2 was the only site where DON concentrations decreased (Table 1) and DOC / DON
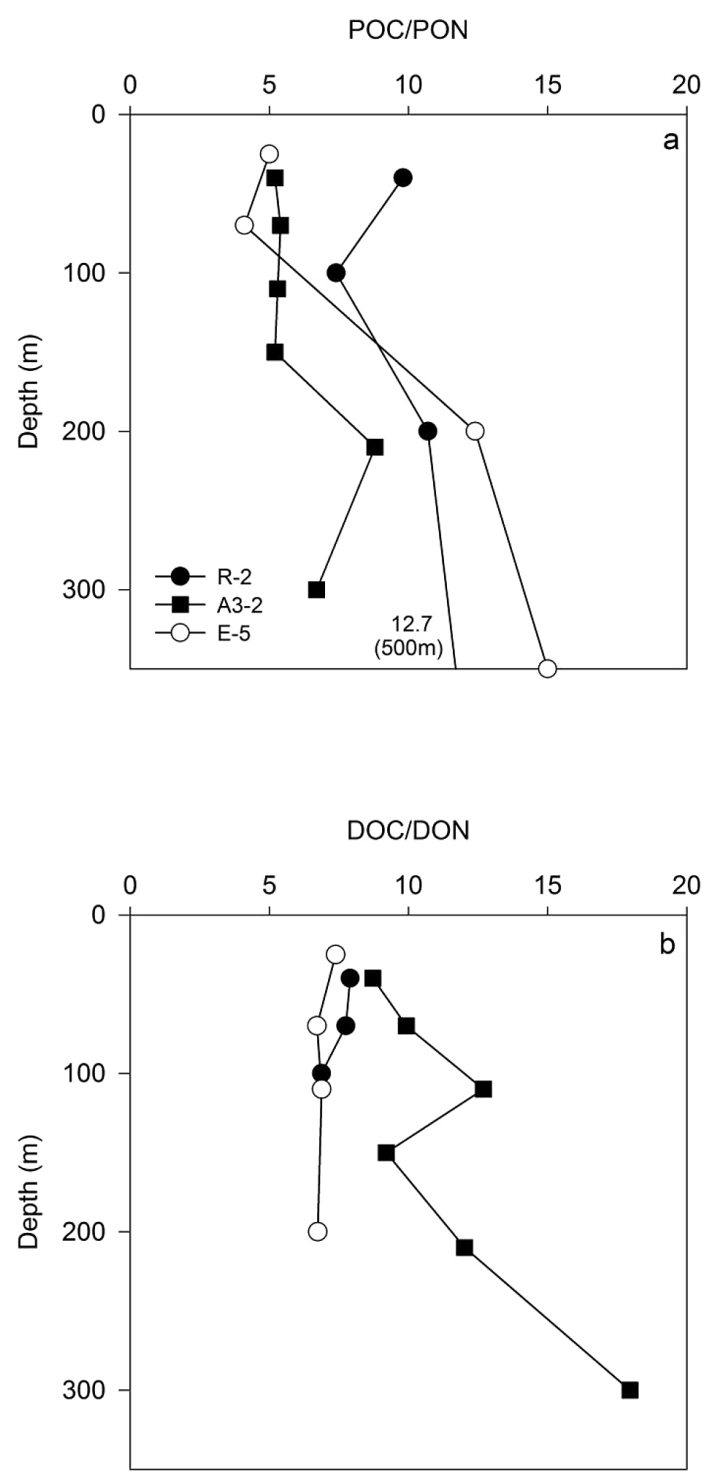

Figure 1. Carbon to nitrogen atomic ratios in the (a) particulate and (b) dissolved fractions for three representative stations (R-2, A3-2, E-5) at $0-350 \mathrm{~m}$ depth. The value close to the station R-2 profile is the next data point at $500 \mathrm{~m}$. Ratios cannot be quantified at certain depths because elementary data were not available (Table 1).

ratios increased with depth (Fig. 1b). This indicates that $\mathrm{N}$ rich dissolved organic molecules at station A3-2 are more easily or rapidly degraded than those from the other stations.

\subsection{Amino acid concentrations}

Table 1 presents AA concentrations measured in the particulate and dissolved fractions. As expected, the most productive stations (A3-2, E-5, and TEW-2) had the highest concentrations of particulate THAA. The water collected at the surface of these stations contained between 539 and $821 \mathrm{nM}$ of particulate THAA, while concentrations were $162-223 \mathrm{nM}$ 
in the surface waters of stations R-2 and E-1. Though deep waters contained less particulate THAA than surface waters at all stations, the decrease with depth was much faster at the bloom sites. These concentrations dropped by a factor of 20 and 37 at stations E-5 and A3-2, respectively, but only by a factor of $\sim 5$ at stations R-2 and E-1. At stations R-2 and $\mathrm{E}-1$, particulate THAA concentrations were maximal in the subsurface layer (40-100 m), and not at the surface like for bloom locations. This suggests a production of particulate THAA in the subsurface or a localized removal mechanism (e.g., photo-oxidation) in the first meters of the water column at stations R-2 and E-1.

In contrast to particulate THAA, concentrations of dissolved AA (combined and free AA) were generally higher at the less productive locations (R-2 and E-1; up to $495 \mathrm{nM}$ ) than at the bloom sites (A3-2 and E-5; 128-292 nM) for similar depths (Table 1). The shallow station TEW-2 also had high concentrations (403-489 nM). However, a greater proportion of dissolved AA were free AA at the surface of stations A3-2 and E-5 compared to station R-2 (13.5-23.6\% vs. $11.3 \%$; Table 1). Station A3-2 exhibited the highest concentrations of free AA (52-69 nM; Table 1), but lower dissolved combined AA (e.g., in proteins and peptides) concentrations than station R-2.

Concentrations of total dissolved AA decreased with depth, by a factor 1.4-2.2 (Table 1), except in the shallow water column at station TEW-2. The decrease in free AA was more important (factor 3.4-5.2). These trends were more pronounced at the bloom station A3-2, but were not as marked as for particulate THAA.

\subsection{Amino acid yields and diagenetic markers}

AA are the most abundant organic $\mathrm{N}$-molecules in nature. We thus expect to see similar trends in the proportions of $\mathrm{N}$ and of THAA in POM as indicated by POC / PON (Fig. 1a) and $\% \mathrm{POC}_{\mathrm{AA}}$ (particulate organic carbon quantified as amino acids) (Fig. 2a), respectively. Both parameters indicated higher proportions of $\mathrm{N}$-molecules in $\mathrm{POM}$ at stations A3-2 and E-5 and a decrease in these proportions with depth at all stations. The decrease in $\% \mathrm{POC}_{\mathrm{AA}}$ was particularly marked at stations A3-2 and E-5 where THAA accounted for $22-25 \%$ of POC in the surface waters, but only for 4.2$4.9 \%$ below $300 \mathrm{~m}$ (Fig. 2a). Particulate THAA accounted for $30-51 \%$ of PON in the surface of the more productive stations and for $27 \%$ at stations R-2, and these proportions decreased with depth at all stations, especially at station A3-2 (not shown). The degradation of particulate THAA was thus more rapid than that of other $\mathrm{N}$ molecules.

Dissolved AA contributed to only $0.86-2.7 \%$ of DOC at

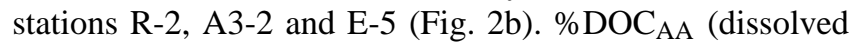
organic carbon quantified as amino acids) were slightly higher in the surface sample of stations E-1 and TEW-2 (2.4$4.4 \%$, E-1 and TEW-2 data not shown). The only consistent vertical trend was observed at station $\mathrm{A} 3-2$ where $\% \mathrm{DOC}_{\mathrm{AA}}$
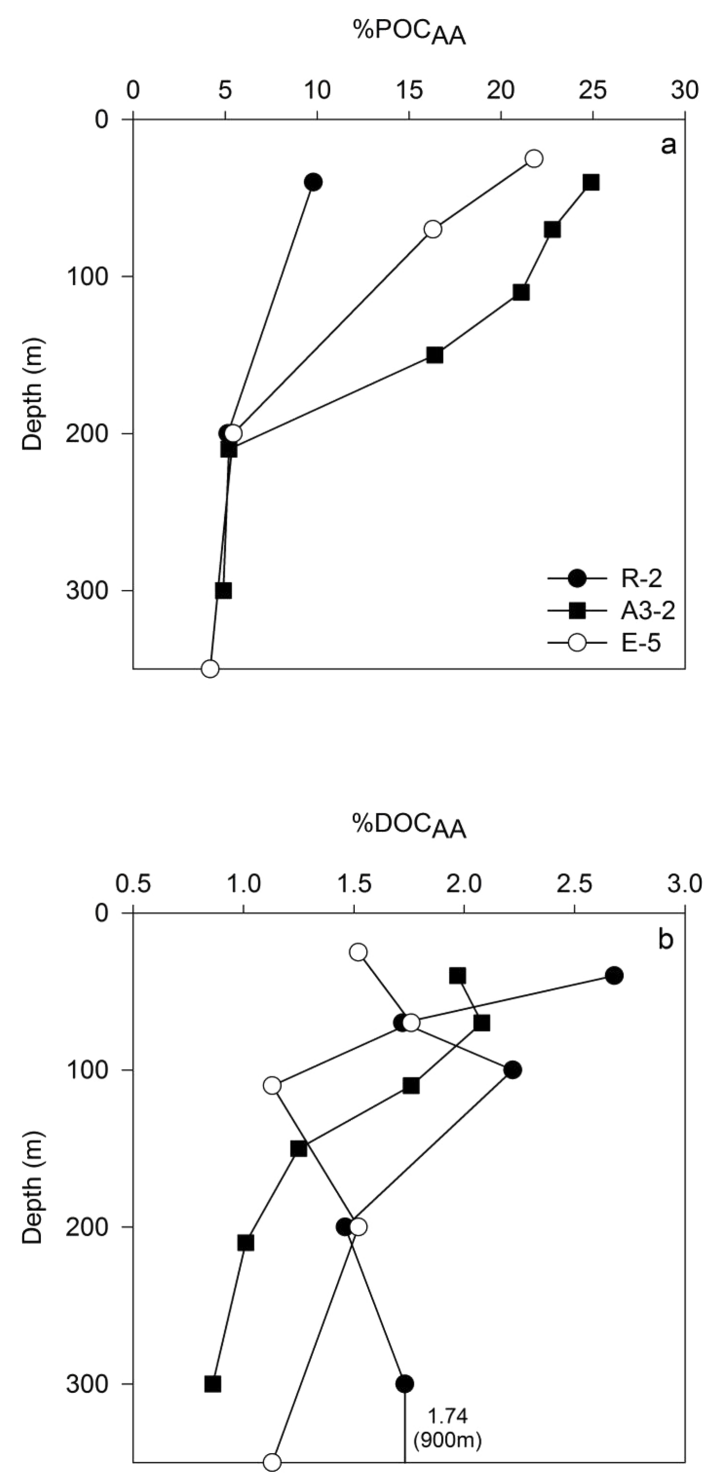

Figure 2. Proportion of (a) particulate and (b) dissolved organic carbon quantified as amino acids $\left(\% \mathrm{POC}_{\mathrm{AA}}\right.$ and $\left.\% \mathrm{DOC}_{\mathrm{AA}}\right)$ for three representative stations (R-2, A3-2, E-5) at 0-350 m depth. The value close to the station R-2 profile is the next data point at $900 \mathrm{~m}$.

decreased with depth from $\sim 2$ to $0.86 \%$. This suggests a preferential removal of dissolved AA with depth at this bloom station. This trend is not observed or is less marked at the other stations. Dissolved AA contributed to $2.3-8 \%$ of DON with no trend according to station or depth (not shown).

During degradation, the mol\% D-AA should increase and the DI should decrease. These markers indicated that POM from station R-2 was more altered than the POM from the other stations (Figs. 3a, 4a), in agreement with its lower $\mathrm{N}$ and THAA contents. However, mol\% D-AA and DI did not show consistent trends with depth, except for mol\% D-AA at station R-2 (Fig. 3a) and for DI in deep waters only (Fig. 4a). Clearly, these markers were not as sensitive, or effective, as 

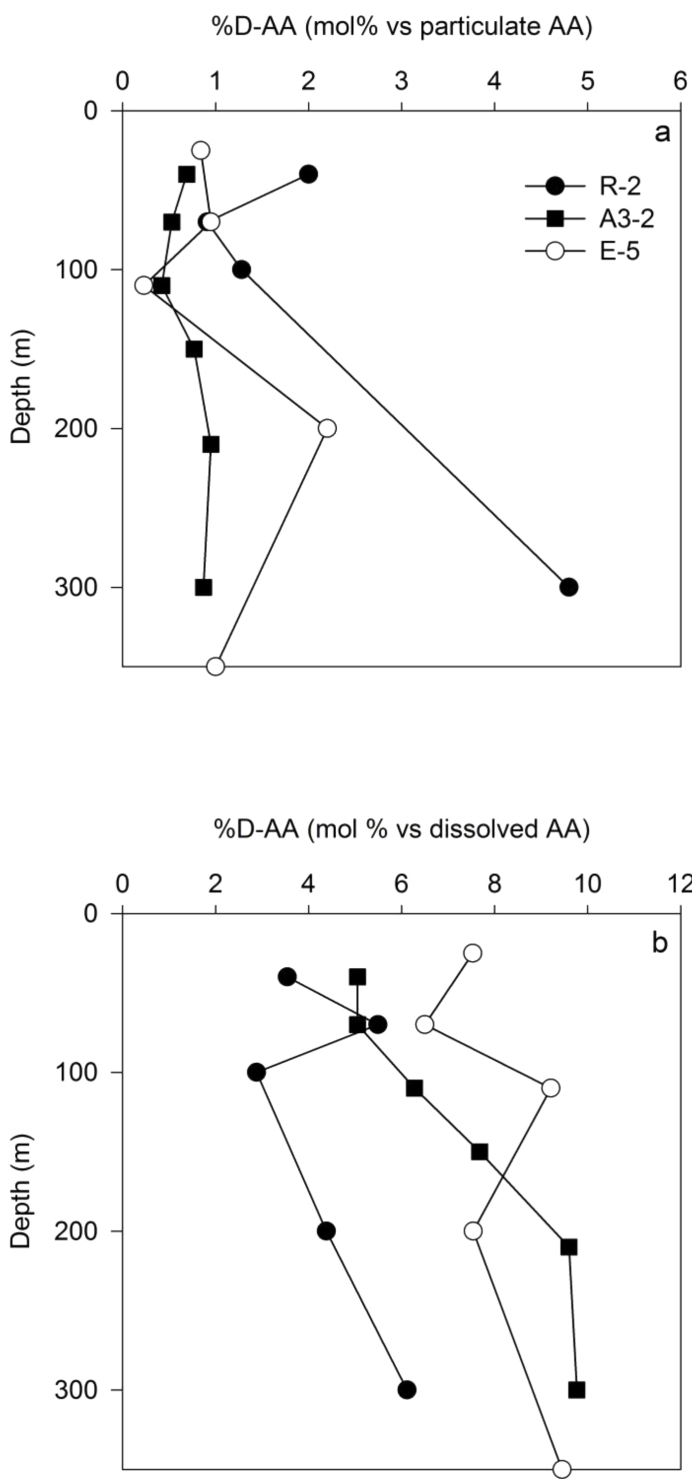

Figure 3. Proportion of D-amino acids (\%D-AA) versus total amino acids (AA) in the (a) particulate and (b) dissolved fractions for three representative stations (R-2, A3-2, E-5) at 0-350 m depth.

$\% \mathrm{POC}_{\mathrm{AA}}$ (or POC / PON) for tracking POM degradation with depth in the present study. In the dissolved fraction, mol\% D-AA and DI values suggest, once again, that DOM from station R-2 was less altered (Figs. 3b, 4b). However, no sign of alteration with depth was observed at this station. In fact, the only station showing a clear increase of DOM alteration state with depth was, once again, A3-2 (Figs. 3b, 4b). From 40 to $300 \mathrm{~m}$, mol\%D-AA went from 5 to $10 \%$ and the DI from 0.5 to -1.7 in DOM. The increase in mol\%D-AA in total OM (POM and DOM) with depth at station A3-2 was even more important (from $\sim 2$ to $8 \%$, not shown).
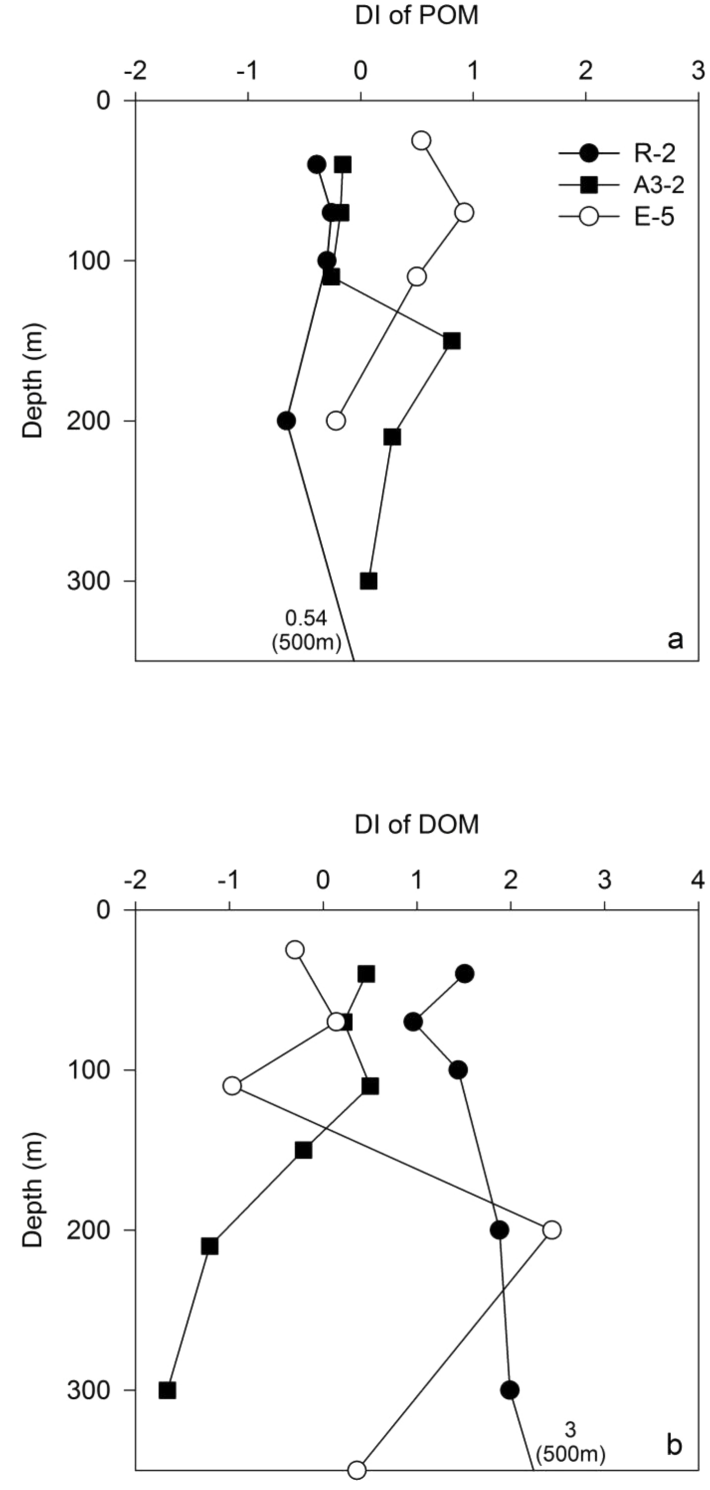

Figure 4. DI of (a) POM (Dauwe et al., 1999) and (b) DOM (Peter et al., 2012) calculated for three representative stations (R-2, A3-2, E-5) at $0-350 \mathrm{~m}$ depth. Values close to the station R-2 profiles are the next data point at $500 \mathrm{~m}$.

\subsection{Markers of organic matter origin}

The average values of Ser + Thr and Asp / Gly found in diatoms, coccolithophores and bacteria (Muller et al., 1986; Cowie and Hedges, 1992) are presented in Fig. 5, along with the values measured here at stations A3-2 and E-5. All the data points for POM (open circles) are near average values (open boxes) found in diatoms or between those of diatoms and bacteria, suggesting that the POM mostly originated from diatoms and bacteria. Except for one data point at each of the other stations having an Asp / Gly ratio of over 1.5 , the same conclusion can be stated for the other studied 


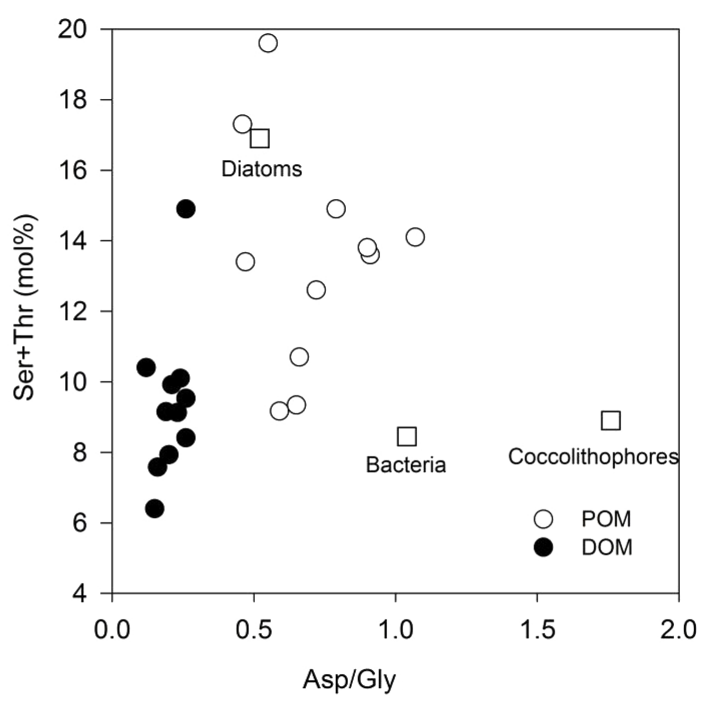

Figure 5. Molar contribution of serine + threonine $(\mathrm{Ser}+\mathrm{Thr})$ versus the molar ratio of aspartic acid and glycine (Asp / Gly) in the particulate and dissolved organic matter (POM and DOM) of stations A3-2 and E-5. Average values for diatoms, coccolithophores, and bacteria are based on Muller et al. (1986) and Cowie and Hedges (1992).

locations (not shown). No trend with depth was observed for Ser + Thr, but Asp / Gly generally decreased with depth (not shown). Gly is known to be selectively preserved during POM degradation (Dauwe et al., 1999). Changes in the composition of AA during degradation (e.g., microbial) are certainly responsible for the lower Ser + Thr and Asp + Gly values measured in DOM (Fig. 5).

Chlorophyll $a$ and D-AA can be used to estimate the proportions of organic matter associated with phytoplankton (cells) and bacteria (cells and detritus), respectively. The ratios of chlorophyll $a$ to POC concentrations (concentrations in Table 1) at stations A3-2 and E-5 are more than twice those measured in the HNLC station R-2. This difference can be due to a higher proportion of phytoplanktonic cells in the POM from the bloom and/or to lower intracellular chlorophyll content in the phytoplankton of the HNLC region. Assuming that diatom-dominated phytoplankton communities have 40 times more carbon than chlorophyll $a$ on a per cell basis (Sathyendranath et al., 2009), calculations indicated that phytoplankton biomass could account for $14 \%$ of POC in the surface water of station R-2, but for 35-63\% in the surface waters of the other stations (not shown), except at $30 \mathrm{~m}$ of TEW-2 where $81 \%$ was calculated. Estimates were much lower in the deep waters, with $2.3 \%$ calculated at station R-2 (200 m) and 8.3\% at station A3-2 (300 m). This approach takes mostly into account phytoplankton cells (vs. altered fragments) considering that a rapid decrease in chlorophyll $a$ content is expected in phytoplankton detritus.

D-AA can be used to estimate the proportions of OM coming from bacterial cells and altered cell fragments or detri- tus. D-Asx yields varied from $<2$ to $31.7 \mathrm{nmol} \mathrm{mg}^{-1}$ POC and D-Glx yields varied from $<2$ to $18.1 \mathrm{nmol} \mathrm{mg}^{-1} \mathrm{POC}$ (Table 2). In both cases, the highest values were measured above $200 \mathrm{~m}$ in the water columns. D-Ala yields were highly variable, $<2-68.8 \mathrm{nmol} \mathrm{mg}^{-1}$ POC with no clear trend with depth. The sample collected at $200 \mathrm{~m}$ at station R-2 exhibited relatively high values for each D-Asx, D-Glx and D-Ala (31.7, 18.1 and $53.7 \mathrm{nmol} \mathrm{mg}^{-1}$ POC, respectively), suggesting a greater contribution of bacteria to POC in this sample. Average yields reported in cultured marine bacteria (Kaiser and Benner, 2008) represent 15,48 and $50 \mathrm{nmol} \mathrm{mg}^{-1} \mathrm{POC}$ for D-Asx, D-Glx and D-Ala, respectively (Table 2). Comparisons between these values and those measured here in POM suggest that a significant, although variable, fraction of POC can be from bacteria. For instance, at station A3-2, where higher POC concentrations increase estimation accuracy and precision, D-Glx and D-Ala yields suggest that $\sim 5-$ $20 \%$ of the POC was from bacteria. However, the lack of correlations, or consistent trends, between the D-AA biomarkers and the large ranges of D-AA yields in POM (and bacteria) makes it difficult to provide estimates of the percentages of POM coming from bacteria based on this approach.

D-AA yields in the dissolved fraction were much more consistent (Table 2). Figure 6 shows average values measured in DOM produced by bacteria (Kaiser and Benner, 2008) and in DOM from surface $(0-120 \mathrm{~m})$ and deep waters $(>120 \mathrm{~m})$ at stations impacted (A3-2 + E-5) or not (R-2 + E-1) by the bloom. D-Asx and D-Ala yields suggest that $16.5-35 \%$ of this DOC is from bacteria, with the lowest estimates found in the deep waters of stations R-2 and E-1. Similar trends, but lower estimates (10.4-17.5\%) were obtained when DGlx yields are used. D-Glx yields in bacterial DOM were highly variable (Kaiser and Benner, 2008), and the reference average value used here might be higher than that of the bacterial DOM produced in the studied waters.

\section{Discussion}

\subsection{Amino acids in the Southern Ocean}

This study presents the first detailed quantification of particulate and dissolved AA in the Southern Ocean. The measured concentrations, yields, and relative distributions of AA in POM and DOM were in the range of values previously found in the open equatorial Pacific (Lee et al., 2000), the coastal waters of the Arctic (Dittmar et al., 2001; Shen et al., 2012) and North Atlantic Ocean (Bourgoin and Tremblay, 2010), and in the polar front zone of the Southern Ocean (Panagiotopoulos et al., 2002). THAA represented between 21 and $25 \%$ of POC in the surface waters of bloom sites, which is close to the $27 \%$ measured in suspended particles at the chlorophyll maximum depth in the equatorial Pacific (Lee et al., 2000). Such high values are expected when protein-rich plankton represents an important part of POM (see Sect. 4.2 
Table 2. Yields of D-AA in particulate and dissolved fractions along with average yields measured in cultured bacteria and bacterial DOM.

\begin{tabular}{|c|c|c|c|c|c|c|c|}
\hline \multirow[t]{2}{*}{ Stations } & \multirow{2}{*}{$\begin{array}{c}\text { Depth } \\
(\mathrm{m})\end{array}$} & D-Asx ${ }^{a}$ & D-Glx ${ }^{b}$ & D-Ala ${ }^{c}$ & D-Asx & D-Glx & D-Ala \\
\hline & & \multicolumn{3}{|c|}{$\mathrm{nmol}(\mathrm{mg} \text { POC })^{-1}$} & \multicolumn{3}{|c|}{$\mathrm{nmol}(\mathrm{mg} \mathrm{DOC})^{-1}$} \\
\hline \multirow[t]{2}{*}{ R-2 (HNLC) } & 40 & 10.2 & 2.83 & 13.9 & 5.31 & 1.77 & 10.6 \\
\hline & 70 & nd & nd & nd & 6.09 & 1.59 & 9.75 \\
\hline \multirow[t]{6}{*}{27 Oct $2011^{\mathrm{g}}$} & 100 & 7.06 & 6.36 & 68.8 & 6.52 & 1.81 & 4.70 \\
\hline & 200 & 31.7 & 18.1 & 53.7 & 4.27 & 0.81 & 7.17 \\
\hline & 300 & nd & nd & nd & 6.58 & 1.63 & 11.3 \\
\hline & 500 & nd & nd & nd & 3.80 & 1.06 & 7.69 \\
\hline & 900 & 5.48 & 8.22 & nd & 4.85 & 1.84 & 10.5 \\
\hline & 1300 & nd & nd & nd & 5.30 & 1.82 & 9.53 \\
\hline A3-2 & 40 & 13.5 & 9.33 & 5.34 & 6.36 & 2.61 & 11.0 \\
\hline \multirow[t]{5}{*}{17 Nov $2011^{\mathrm{g}}$} & 70 & 9.80 & 8.99 & 2.17 & 6.88 & 2.56 & 12.1 \\
\hline & 110 & 6.12 & 7.65 & 2.62 & 7.29 & 2.63 & 11.9 \\
\hline & 150 & 7.30 & 6.25 & 6.77 & 6.59 & 2.62 & 11.0 \\
\hline & 210 & nd & 2.40 & 7.51 & 6.88 & 2.61 & 11.6 \\
\hline & 300 & nd & 6.57 & nd & 6.80 & 2.09 & 10.5 \\
\hline E-5 & 25 & 14.8 & 10.5 & 4.25 & 7.44 & 3.24 & 13.5 \\
\hline \multirow[t]{4}{*}{$18 \operatorname{Nov} 2011^{\mathrm{g}}$} & 70 & 9.67 & 4.37 & 10.4 & 8.14 & 3.38 & 12.9 \\
\hline & 110 & nd & nd & nd & 7.32 & 2.87 & 13.0 \\
\hline & 200 & 7.79 & 1.91 & 10.8 & 6.95 & 2.50 & 13.0 \\
\hline & 350 & 2.13 & 0.55 & nd & 6.82 & 2.73 & 14.1 \\
\hline E-1 & 20 & 1.70 & 7.13 & nd & 5.64 & 2.45 & 12.1 \\
\hline \multirow[t]{6}{*}{30 Oct $2011^{\mathrm{g}}$} & 40 & 5.27 & 4.62 & 14.0 & 5.39 & 2.47 & 11.2 \\
\hline & 70 & nd & 2.70 & 4.34 & 7.47 & 2.92 & 11.4 \\
\hline & 120 & nd & 7.09 & nd & 6.51 & 2.44 & 11.3 \\
\hline & 200 & nd & 2.17 & nd & 2.69 & 2.44 & 9.94 \\
\hline & 500 & nd & nd & nd & 1.94 & 1.88 & 5.63 \\
\hline & 1300 & 8.39 & nd & nd & 2.63 & 2.25 & 8.17 \\
\hline TEW-2 & 15 & nd & 2.85 & nd & 8.39 & 4.13 & 14.7 \\
\hline \multirow[t]{2}{*}{31 Oct $2011^{\mathrm{g}}$} & 30 & 21.3 & 14.3 & nd & 8.46 & 4.24 & 15.8 \\
\hline & 62 & 9.26 & 2.74 & nd & 8.12 & 4.10 & 16.0 \\
\hline Bacteria $^{\mathrm{d}}$ & & $15(22)$ & $48(26)$ & $50(19)$ & $24(3)$ & $17(7)$ & $35(7)$ \\
\hline
\end{tabular}

below) (Cowie and Hedges, 1992; 1994). Concentrations of chlorophyll $a$ and POM were highest in the surface water of the bloom station A3-2, consistent with a greater production of biomass induced by iron inputs. In contrast, THAA represented $10 \%$ of POC at station $\mathrm{R}-2$, which is expected in more-altered POM (Cowie and Hedges, 1994).

A particularity of the Southern Ocean surface waters are the lower DOC concentrations compared to other oceans (i.e., $\sim 50$ vs. 70-80 $\mu \mathrm{M}$ ) (Hansell, 2013). Here, AA accounted for only $0.9-4.4 \%$ of DOC, which is in the range of values found in other regions (Benner, 2002; Bourgoin and Tremblay, 2010; Shen et al., 2012). However, AA yields in the DOC of HNLC surface water $(2.7 \%)$ were about twice that measured in the oligotrophic North Pacific near Hawaii (Kaiser and Benner, 2008). This suggests more favorable conditions for AA accumulation/preservation in the HNLC of the Southern Ocean.

\subsection{Origin and fate of POM}

Molecular AA markers (i.e., Ser + Thr, Asp / Gly and D-AA yields) indicated, at least qualitatively, that the POM at the bloom sites mostly originated from diatoms and bacteria. Different approaches can be used to estimate the proportion of each of these components of the plankton community. Pigment analysis and microscopic observations confirmed that diatoms were abundant in surface waters of the bloom sites 

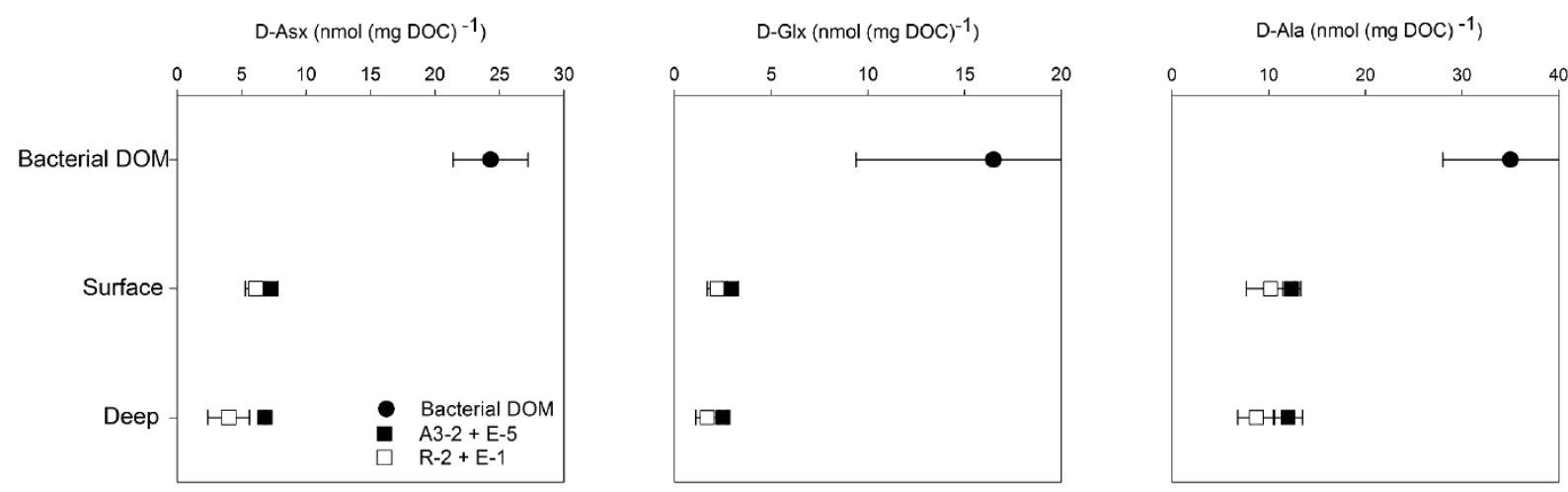

Figure 6. Average C-normalized yields of D-aspartic acid or D-asparagine (D-Asx), D-glutamic acid or D-glutamine (D-Glx), and D-alanine (D-Ala) in bacterial DOM (Kaiser and Benner 2008) and DOM from surface (0-120 m) and deep waters $(>120 \mathrm{~m})$ at stations impacted (A3-2 + E-5) or not (R-2 + E-1) by the bloom. Error bars represent standard deviations.

(Lasbleiz et al., 2014). Species-specific biovolume determination in the euphotic layer (between the surface and $0.01 \%$ PAR - photosynthetically active radiation) revealed that diatoms accounted, on average, for $44 \%$ of POC at station A32, while their contribution to POC was only $5 \%$ at the HNLC site (Lasbleiz, 2014) (Table 3). These observations are consistent with the present estimates based on chlorophyll $a$ concentrations, indicating that phytoplankton cells could account on average for $45 \%$ of POC in the surface waters of station A3-2, but $14 \%$ of POC in the surface waters of station R-2 (Table 3). The lower proportion of diatoms among the phytoplankton community at station R-2 is in agreement with direct observations (Lasbleiz et al., 2014). These estimates were 5-7 times lower below $200 \mathrm{~m}$ at both locations (Table 3). In deep waters, the phytoplankton contribution to POC is thus likely dominated by detrital material (vs. intact cells). Laurenceau et al. (2014) used microscopic observations of material collected in gel traps and estimated that phytodetrital aggregates represented 41 and $34 \%$ of POC at stations A3-2 and R-2, respectively, in sinking particles collected at $210 \mathrm{~m}$ (Table 3). Both types of estimates show the same trend of a higher phytoplankton contribution at station A3-2. The higher percentage contribution obtained for the gel traps is most likely due to the fact that this approach considers both living and dead phytoplankton cells, and that particles defined as phytodetrital aggregates can contain POC from other origins (e.g., bacteria).

D-AA yields were used to estimate the proportion of POC from bacteria (cells and altered debris of bacteria). However, some extreme and inconsistent values were measured in the present dataset. Extreme values or the disagreement between D-AA yields are probably caused by the fact that yields in POM were calculated by the difference between the chromatographic peaks measured in unfiltered and filtered water samples. In many samples this difference was very small because of the very low POM concentrations, increasing the uncertainty of these yields. Different dynamics between D-
Asx, D-Glx et D-Ala in the studied POM could also explain inconsistent values. This appears to be the case at station A32 , where D-Glx and D-Ala markers were not always in agreement, despite the increased estimation accuracy and precision due to the higher POC concentrations. For instance, at $70 \mathrm{~m}$, at this site, estimates based on D-Glx and D-Ala were 19 and $5 \%$, respectively (not shown). Averages suggest that $\sim 15 \%$ of the POC originated from bacteria at all depths at station A3-2 (Table 3, Bacteria total). Using the same approach and markers, Kaiser and Benner (2008) estimated that about $25 \%$ of POC was of bacterial origin in oligotrophic areas of the North Pacific and North Atlantic.

An independent approach, based on cell counts of autotrophic (unpublished data) and heterotrophic bacteria (Christaki et al., 2014) and conversion of cell counts to carbon units using $250 \mathrm{fg} \mathrm{Cell}^{-1}$ for autotrophic (Campbell et al., 1994) and $12.4 \mathrm{fg} \mathrm{Cell}^{-1}$ for heterotrophic bacteria (Fukuda et al., 1998), revealed that only 2-3\% of POC are accounted for by bacterial cells as determined by flow cytometry in the surface waters at station A3-2 (Table 3, Bacteria biomass). However, there was a steady increase of this proportion with depth at station A3-2, reaching $10 \%$ at $300 \mathrm{~m}$. When compared to the D-AA estimate of $\sim 15 \%$ of POC originating from bacteria, it appears that intact bacterial cells represent a small proportion $(<20 \%)$ of the total bacterial contribution (living + detritus) in the surface water, which is in agreement with previous studies (e.g., White and Howes, 1994; Bourgoin and Tremblay, 2010). However, intact bacterial cells appear to dominate $(67 \%)$ the bacterial contribution in the deep waters at the bloom site. This increase in bacterial cell contribution with depth was not observed at the HNLC site where proportions fluctuated between 4 and $7 \%$ of POC. Different trends have been reported in previous studies. As observed here at the bloom site, the proportion of POC as bacterial biomass increased with depth in the St. Lawrence Gulf (Bourgoin and Tremblay, 2010). This trend was caused by a depletion of bacterial POM with depth 
Table 3. Summary of the characteristics of POM and DOM in HNLC waters (station R-2) and at the bloom site above the Kerguelen Plateau (station A3-2). Surface refers to 10-90 m depth layer and deep refers to 210-300 m depth. Contributions to POM and DOM are average values given as percent of bulk organic carbon.

\begin{tabular}{|c|c|c|c|c|c|}
\hline \multirow[t]{2}{*}{ Depth } & \multirow[t]{2}{*}{ Parameters } & \multicolumn{2}{|c|}{ POM } & \multicolumn{2}{|c|}{ DOM } \\
\hline & & HNLC & Bloom & HNLC & Bloom \\
\hline \multicolumn{6}{|l|}{ Surface } \\
\hline & $\begin{array}{l}\text { Phytoplankton } \\
\text { diatom cells }{ }^{\mathrm{a}} \\
\text { total cells }{ }^{\mathrm{b}}\end{array}$ & $\begin{array}{l}5 \% \\
14 \%\end{array}$ & $\begin{array}{l}44 \% \\
45 \%\end{array}$ & nd & nd \\
\hline & $\begin{array}{l}\text { Bacteria } \\
\text { cells }^{\mathrm{c}} \\
\text { total }^{\mathrm{d}} \\
\text { Alteration state } \\
\text { Alterations with depth }\end{array}$ & $\begin{aligned} & 5 \% \\
&> 15 \% \mathrm{~g} \\
& \text { high } \\
& \text { med }\end{aligned}$ & $\begin{array}{l}3 \% \\
15 \% \\
\text { low } \\
\text { high }\end{array}$ & $\begin{array}{l}\text { nd } \\
30 \% \\
\text { low } \\
\text { low }\end{array}$ & $\begin{array}{c}\text { nd } \\
30 \% \\
\text { med } \\
\text { high }\end{array}$ \\
\hline \multicolumn{6}{|l|}{ Deep } \\
\hline & $\begin{array}{l}\text { Phytoplankton } \\
\text { total cells } \\
\text { phytodetritus } \\
\text { Bacteria } \\
\text { cells }^{\mathrm{c}} \\
\text { total }^{\mathrm{d}} \\
\text { Alteration state }^{\text {f }}\end{array}$ & $\begin{aligned} & 7 \% \\
> & 15 \% \mathrm{~g} \\
& \text { high }\end{aligned}$ & $\begin{array}{l}10 \% \\
15 \% \\
\text { high }\end{array}$ & $\begin{array}{c}\text { nd } \\
25 \% \\
\text { med }\end{array}$ & $\begin{array}{c}\text { nd } \\
30 \% \\
\text { high }\end{array}$ \\
\hline
\end{tabular}

${ }^{a}$ From microscopic counts and biovolume determination (Lasbleiz, 2014).

b Total cells assuming that phytoplankton cells have 40 times more carbon than chlorophyll $a$

(Sathyendranath et al., 2009).

${ }^{\mathrm{c}}$ From cell counts of autotrophic and heterotrophic bacteria and conversion factors (Christaki et

al., 2014).
$\mathrm{d}$ Total bacterial contribution estimated from D-AA yields (see text), for POC it includes living cells and

cell fragments or detritus.

e Alterations promoted by different organic matter inputs or environmental conditions (see text).

${ }^{\mathrm{f}}$ Estimated based on direct observation of sinking particles defined as phytodetrital aggregates

(Laurenceau et al., 2014).

$\mathrm{g}$ Estimates were inconsistent but generally $>15 \%$ (see text).

nd: not determined

med: medium.

that was more intense than the decrease of bacterial biomass with depth. In contrast, Kawasaki et al. (2011) estimated that bacterial detritus represented a greater proportion of POC (vs. living bacterial biomass) at $100 \mathrm{~m}(\sim 7 \%)$ than at $5 \mathrm{~m}$ $(\sim 4.5 \%)$ in an oligotrophic area of the North Pacific gyre. However, autotrophic bacteria accounted for $\sim 13 \%$ of their POC which was about $50 \%$ of the total bacterial contribution (living + detritus). In the present study, autotrophic bacteria (Synechococcus) had low cell numbers $\left(2-10 \times 10^{5}\right.$ cells L $^{-1}$; data not shown). It thus appears that a high lability of bacterial detritus and a low proportion of autotrophic bacteria increase the relative proportion of living bacteria versus bacterial detritus in POC in deep waters as in the present study (see below).

A large fraction of the POM remains of unknown origin, especially in the HNLC site. This fraction could be mostly from detritus of various origins including zooplankton. Laurenceau et al. (2014) estimated that zooplankton fecal pellets represented on average $56 \pm 19 \%$ of POC flux below $110 \mathrm{~m}$ at the studied locations. These pellets contain materials from different origins including phytoplankton (Silver and Gowing, 1991).

The reactivity of POM was markedly higher at the bloom site A3-2 compared to the HNLC site, as revealed by a much more rapid decrease of POM and particulate THAA concentrations with depth. In addition, THAA yields in POM $\left(\% \mathrm{POC}_{\mathrm{AA}}\right.$ and $\left.\% \mathrm{PON}_{\mathrm{AA}}\right)$, reliable indicators of POM alteration or diagenetic state (Cowie and Hedges, 1994; Tremblay and Benner, 2009), indicated that the POM from the bloom was relatively fresh or unaltered, but was more rapidly degraded during sinking than the POM from the HNLC site (Table 3). These findings could explain the lower efficiency of carbon export at $100 \mathrm{~m}$ at the bloom sites A3-2 (5\%) and E-5 (11\%) than in HNLC waters (station R-2, $34 \%$ ) (Planchon et al., 2014). Laurenceau et al. (2014) also found that export efficiencies (at $200 \mathrm{~m}$ ) were negatively correlated to net primary productivity during the same sampling campaign. 
In contrast to THAA yields, no consistent trend in mol\% D-AA and DI values were observed with depth, probably because more intense degradation of bulk POM is required to be detectable with these markers (Davis et al., 2009; Bourgoin and Tremblay, 2010). Our data show that a large fraction of particulate AA is rapidly utilized in surface waters of the bloom. The AA that remain in the POM below the surface layer are probably in more recalcitrant structures. These structures may be too recalcitrant to show significant change in AA composition (i.e., mol\% D-AA and DI values) with depth. In addition, an apparent mismatch between DI values and the expected trend during degradation has been previously observed in the Southern Ocean and was attributed to the unusual AA composition of diatoms, the dominant source of POM (Ingalls et al., 2003).

\subsection{Origin and fate of DOM}

Although an important fraction of the primary production is transferred to the DOM pool (e.g., 30-50\% as short lived labile DOM: Pomeroy et al., 2007; Obernosterer et al., 2008; Hansell, 2013), it was not possible to estimate the phytoplankton contribution to bulk DOC with the markers used in the present study. By contrast, the bacterial contribution to DOC was estimated using D-AA yields, indicating that 16.5$35, \%$ of bulk DOC was of bacterial origin with no consistent trend with depth or location. These contributions were near $30 \%$ in surface waters, and similar between Fe-fertilized waters and the HNLC site (Table 3). Similarly, DOC concentrations were not substantially different among sites (i.e., 3$4 \mu \mathrm{M}$ greater in the bloom). Taken together, these results suggest that DOM production was counterbalanced by bacterial consumption (Christaki et al. 2014) of DOM from bacteria and other sources. The relatively constant bacterial contribution to DOC measured here $(\sim 30 \%)$ or in the North Atlantic and North Pacific ( $25 \%$, Kaiser and Benner, 2008) indicates that bacterial DOM has an average reactivity similar to bulk DOM and contributes to all DOM fractions, from labile to refractory DOM.

This study shows for the first time the contrasting fates of the DOM produced during natural iron fertilization and the DOM from an HNLC region (Table 3). The bloom site A3-2 clearly shows intense DOM alteration within the water column. At station A3-2, all the molecular diagenetic markers $\left(\% \mathrm{DOC}_{\mathrm{AA}}, \mathrm{mol} \% \mathrm{D}-\mathrm{AA}, \mathrm{DI}\right.$ values) indicated that surface DOM was less altered than deep water DOM. In contrast, DOM in HNLC surface waters revealed a lower alteration state that did not change with depth (Table 3). The DOM produced during the bloom was thus more rapidly degraded and mineralized, and this pattern reflects well that observed for POM. Mixing of deep and surface water layers at station A32 could explain the gradual character of the trends observed in profiles of DOM molecular markers at this location. Despite the fact that a water-column stratification was present during sampling, with a surface mixed layer of $153 \mathrm{~m}$, station
A3-2 is located above the Kerguelen Plateau which is surrounded by deeper areas and thus a more intense or frequent vertical mixing may occur. However, this probable mixing cannot explain why station A3-2 had more altered DOM (and lower dissolved AA) than in the HNLC area even in deep waters.

A surprising finding of the present study is the lower total dissolved AA concentrations and yields in surface water DOM in the bloom sites as compared to HNLC waters. These differences were due to $\sim 30 \%$ more dissolved combined AA in HNLC waters. By contrast, free AA had higher concentrations and represented a greater proportion of dissolved AA at the bloom sites (13.5-23.6\% vs. $11.3 \%$ at HNLC) which likely reflects the higher phytoplankton activity and associated DOM release mechanisms (Fuhrman, 1987; Sarmento et al., 2013).

We propose four possibilities that could explain the lower alteration state of DOM and the higher concentration of dissolved combined AA in less productive sites (i.e., stations R-2 and E-1) compared to the bloom sites (i.e., stations A3-2 and E-5). First, the higher quantities of labile DOM produced at the bloom sites could induce a priming effect (Bianchi, 2011). These large quantities of labile DOM (e.g., free AA) induce a strong microbial response (Christaki et al., 2014) and the energy gained through labile DOM may allow for the degradation of more recalcitrant DOM including dissolved combined AA. This degradation was particularly marked within the water column of the bloom site A32. As a consequence, the DOM at the bloom sites appears more altered than the DOM from the HNLC site (Table 3). The higher concentration of more altered DOM in the bloom sites is consistent with the microbial carbon pump concept in which marine microbes transform labile DOM into refractory DOM (Jiao et al., 2011). Important inputs of labile DOM likely stimulate bacterial activity leading to more intense DOM degradation and production of more recalcitrant DOM. The more rapid degradation of the DOM from the bloom is consistent with a recent study in Arctic fjords (Osterholz et al., 2014). Their findings suggest that DOM produced during the spring/summer bloom is degraded in a few weeks by a specialized resident microbial community. Second, another reason for the slower DOM degradation and the accumulation of combined dissolved AA in HNLC waters is an iron limitation for heterotrophic bacteria (Obernosterer et al., 2014). Third, the DOM in HNLC waters can be involved in physicochemical processes (e.g., inter-molecular interactions, partial photooxidation) that protect DOM such as dissolved combined AA from microbial attack (Keil and Kirchman, 1994). Protection mechanisms may be too slow to significantly reduce the microbial degradation rate of the labile DOM produced during the bloom. Finally, a fourth explanation could be that HNLC waters produce DOM molecules, including ones that contain combined AA, which are more recalcitrant to degradation. 
The first three explanations are associated with unfavorable conditions for DOM degradation in HNLC areas, namely low quantity of labile or priming DOM, iron limitation, and DOM protection. The last explanation implies that the DOM produced in the HNLC region is intrinsically more recalcitrant than the DOM produced during the bloom. Though the DOM from the HNLC site appears less degraded, the relative lability or recalcitrance of this DOM remains unknown. This notion of substrate quality "may only be valid in the context of the ambient environment" or conditions (Bianchi, 2011). Freshly produced and highly altered or old molecules can persist in unfavorable conditions, but be degraded in another environment.

\section{Conclusions}

Important differences in POM and DOM origins, compositions, and alterations were observed between the HNLC region and the areas where a phytoplankton bloom was induced by natural iron fertilization in the Southern Ocean. Phytoplankton cells represent an important fraction of POC $(\sim 45 \%)$ in the surface waters at the bloom sites, while the bacterial total (cells and detritus) contribution was much lower $(\sim 15 \%)$. Molecular indicators demonstrate that POM originating from the bloom was more rapidly degraded during sinking than the POM from the HNLC site. The fraction of the bloom POM that was transferred to DOM is unknown, but $\sim 30 \%$ of the DOM appears to come from bacteria. As for POM, the DOM from the bloom sites was involved in more intense degradation processes. In contrast, the DOM in HNLC waters was less altered and showed no significant alteration throughout the water column. The bloom induced by natural iron fertilization probably leads to favorable conditions (e.g., large quantities of labile $\mathrm{OM}$ ) supporting high microbial activity (Christaki et al., 2014) and enhanced POM and DOM degradation. The more intense degradation in bloom sites reduces the carbon export efficiency and the net impact of such blooms on the global carbon budget. However, a higher microbial activity appears to also lead to a greater production of more recalcitrant DOM or a more active microbial carbon pump (Jiao et al., 2011).

Acknowledgements. We thank Louise Oriol and Karine Escoubeyrou for their help during sampling and analyses. We also thank our many colleagues who participated in the collection of various data sets, the KEOPS coordinator S. Blain, the chief on board, B. Quéguiner, and the crew aboard the R/V Marion Dufresne for their help in the successful completion of the cruise. C. Panagiotopoulos and an anonymous reviewer provided valuable comments that improved the manuscript. This research was supported by the project KEOPS2 (ANR-10-Blanc-614, LEFE INSU, CNES, IPEV) and the Natural Science and Engineering Research Council of Canada (NSERC). L. Tremblay received support from the UPMC during his sabbatical stay at the Laboratoire
d'Océanographie Microbienne. We are grateful to the BIO2MAR platform (http://bio2mar.obs-banyuls.fr) for providing access to instrumentation.

Edited by: B. Quéguiner

\section{References}

Aminot, A. and Kérouel, R.: Dosage Automatique des Nutriments dans les Eaux Marines: Meìthodes en Flux Continu, Ifremer, France, 188 pp., 2007.

Asano, Y. and Lübbehüsen, T. L.: Enzymes acting on peptides containing d-amino acid, J. Biosci. Bioeng., 89, 295-306, 2000.

Benner, R.: Chemical Composition and Reactivity, in: Biogeochemistry of Marine Dissolved Organic Matter, edited by: Hansell, D. and Carlson, C., Academic Press, San Diego, 59-90, 2002.

Benner, R. and Strom, M.: A critical-evaluation of the analytical blank associated with DOC measurements by high-temperature catalytic-oxidation, Mar. Chem., 41, 153-160, 1993.

Bianchi, T. S.: The role of terrestrially derived organic carbon in the coastal ocean: a changing paradigm and the priming effect, P. Natl. Acad. Sci. USA, 108, 19473-19481, 2011.

Blain, S., Carlotti, F., Christaki, U., Corbière, A., Durand, I., Ebersbach, F., Fuda, J., Garcia, N., Gerringa, L., Griffiths, B., Guigue, C., Quéguiner, B., Guillerm, C., Jacquet, S., Jeandel, C., Laan, P., Lefèvre, D., Lo Monaco, C., Malits, A., Mosseri, J., Obernosterer, I., Park, Y., Armand, L., Picheral, M., Pondaven, P., Remenyi, T., Sandroni, V., Sarthou, G., Savoye, N., Scouarnec, L., Souhaut, M., Thuiller, D., Timmermans, K., Belviso, S., Trull, T., Uitz, J., van Beek, P., Veldhuis, M., Vincent, D., Viollier, E., Vong, L., Wagener, T., Bombled, B., Bopp, L., Bowie, A., Brunet, C., and Brussaard, C.: Effect of natural iron fertilization on carbon sequestration in the Southern Ocean, Nature, 446, 1070-1074, 2007.

Blain, S., Capparos, J., Guéneuguès, A., Obernosterer, I., and Oriol, L.: Distributions and stoichiometry of dissolved nitrogen and phosphorus in the iron fertilized region near Kerguelen (Southern Ocean), Biogeosciences Discuss., 11, 9949-9977, doi:10.5194/bgd-11-9949-2014, 2014.

Bourgoin, L. and Tremblay, L.: Bacterial reworking of terrigenous and marine organic matter in estuarine water columns and sediments, Geochim. Cosmochim. Ac., 74, 5593-5609, 2010.

Bowie, A. R., van der Merwe, P., Quéroué, F., Trull, T., Fourquez, M., Planchon, F., Sarthou, G., Chever, F., Townsend, A. T., Obernosterer, I., Sallée, J.-B., and Blain, S.: Iron budgets for three distinct biogeochemical sites around the Kerguelen archipelago (Southern Ocean) during the natural fertilisation experiment KEOPS-2, Biogeosciences Discuss., 11, 17861-17923, doi:10.5194/bgd-11-17861-2014, 2014.

Boyd, P. W., Jickells, T., Law, C. S., Blain, S., Boyle, E. A., Buesseler, K. O., Coale, K. H., Cullen, J. J., de Baar, H. J. W., Follows, M., Harvey, M., Lancelot, C., Levasseur, M., Owens, N. P. J., Pollard, R., Rivkin, R. B., Sarmiento, J., Schoemann, V., Smetacek, V., Takeda, S., Tsuda, A., Turner, S., and Watson, A. J.: Mesoscale iron enrichment experiments 1993-2005: synthesis and future directions, Science, 315, 612-617, 2007.

Brückner, H., Haasmann, S., Langer, M., Westhauser, T., Wittner, R., and Godel, H.: Liquid chromatographic determination of d- 
and l-amino acids by derivatization with o-phthaldialdehyde and chiral thiols, J. Chromatogr. A, 666, 259-273, 1994.

Campbell, L., Nolla, H. A., and Vaulot, D.: The importance of Prochlorococcus to community structure in the central North Pacific Ocean, Limnol. Oceanogr., 39, 954-961, 1994.

Christaki, U., Obernosterer, I., Van Wambeke, F., Veldhuis, M., Garcia, N., and Catala, P.: Microbial food web structure in a naturally iron-fertilized area in the Southern Ocean (Kerguelen Plateau), Deep-Sea Res. Pt. II, 55, 706-719, 2008.

Christaki, U., Lefèvre, D., Georges, C., Colombet, J., Catala, P., Courties, C., Sime-Ngando, T., Blain, S., and Obernosterer, I.: Microbial food web dynamics during spring phytoplankton blooms in the naturally iron-fertilized Kerguelen area (Southern Ocean), Biogeosciences, 11, 6739-6753, doi:10.5194/bg-116739-2014, 2014.

Church, M. J., Hutchins, D. A., and Ducklow, H. W.: Limitation of bacterial growth by dissolved organic matter and iron in the Southern ocean, Appl. Environ. Microb., 66, 455-466, 2000.

Consensus Reference Materials Project: http://www.rsmas.miami. edu/groups/biogeochem/CRM.html, last access: 16 January 2015.

Cowie, G. and Hedges, J.: Sources and reactivities of amino-acids in a coastal marine environment, Limnol. Oceanogr., 37, 703-724, 1992.

Cowie, G. and Hedges, J.: Biochemical indicators of diagenetic alteration in natural organic matter mixtures, Nature, 369, 304307, 1994.

Dauwe, B., Middelburg, J. J., Herman, P. M. J., and Heip, C. H. R.: Linking diagenetic alteration of amino acids and bulk organic matter reactivity, Limnol. Oceanogr., 44, 1809-1814, 1999.

Davis, J., Kaiser, K., and Benner, R.: Amino acid and amino sugar yields and compositions as indicators of dissolved organic matter diagenesis, Org. Geochem., 40, 343-352, 2009.

Dittmar, T., Fitznar, H. P., and Kattner, G.: Origin and biogeochemical cycling of organic nitrogen in the eastern Arctic Ocean as evident from D- and L-amino acids, Geochim. Cosmochim. Ac., 65, 4103-4114, 2001.

Dittmar, T., Cherrier, J., and Ludwichowski, K.: The analysis of amino acids in seawater, in: Practical guidelines for the analysis of seawater, edited by: Wurl, O., CRC Press, 67-77, 2009.

Ebersbach, F. and Trull, T.: Sinking particle properties from polyacrylamide gels during the KErguelen Ocean and Plateau compared Study (KEOPS): Zooplankton control of carbon export in an area of persistent natural iron inputs in the Southern Ocean, Limnol. Oceanogr., 53, 212-224, 2008.

Escoubeyrou, K. and Tremblay, L.: Quantification of free, dissolved combined, particulate, and total amino acid enantiomers using simple sample preparation and more robust chromatographic procedures, Limnol. Oceanogr.-Meth., 12, 421-431, 2014.

Fuhrman, J.: Close coupling between release and uptake of dissolved free amino acids in seawater studied by an isotope dilution approach, Mar. Ecol.-Prog. Ser., 37, 45-52, 1987.

Fukuda, R., Ogawa, H., Nagata, T., and Koike, I.: Direct Determination of Carbon and Nitrogen Contents of Natural Bacterial Assemblages in Marine Environments, Appl. Environ. Microb., 64, 3352-3358, 1998.

Gupta, L. and Kawahata, H.: Amino acid and hexosamine composition and flux of sinking particulate matter in the equatorial Pacific at 175 degrees E longitude, Deep-Sea Res. Pt. I, 47, 1937-1960, 2000.

Hansell, D.: Recalcitrant Dissolved Organic Carbon Fractions, Annual Review of Marine Science, 5, 421-445, 2013.

Ingalls, A. E., Lee, C., Wakeham, S. G., and Hedges, J. I.: The role of biominerals in the sinking flux and preservation of amino acids in the Southern Ocean along $170^{\circ} \mathrm{W}$, Deep-Sea Res. Pt. II, 50, 713-738, 2003.

Ittekkot, V., Deuser, W., and Degens, E.: Seasonality in the fluxes of sugars, amino acids, and amino sugars to the deep ocean: Sargasso Sea, Deep-Sea Res., 31, 1057-1069, 1984.

Jiao, N., Azam, F., and Sanders, S.: Microbial carbon pump in the ocean. Washington, DC, Sciences/AAAS, Washington, DC, 2011.

Kaiser, K. and Benner, R.: Hydrolysis-induced racemization of amino acids, Limnol. Oceanogr.-Meth., 3, 318-325, 2005.

Kaiser, K. and Benner, R.: Major bacterial contribution to the ocean reservoir of detrital organic carbon and nitrogen, Limnol. Oceanogr., 53, 99-112, 2008.

Kawasaki, N., Sohrin, R., Ogawa, H., Nagata, T., and Benner, R.: Bacterial carbon content and the living and detrital bacterial contributions to suspended particulate organic carbon in the North Pacific Ocean, Aquat. Microb. Ecol., 62, 165-176, 2011.

Keil, R. G. and Kirchman, D. L.: Abiotic transformation of labile protein to refractory protein in sea water, Mar. Chem., 45, 187196, 1994.

Lasbleiz, M.: Dynamique nutritionnelle du phytoplancton, cycles biogéochimiques du carbone et des éléments biogènes associées (N,P,Si) et disponibilité du fer dans l'Océan Austral - programme KEOPS 2, PhD thesis, Aix Marseille Université, France, 2014 (in French).

Lasbleiz, M., Leblanc, K., Blain, S., Ras, J., Cornet-Barthaux, V., Hélias Nunige, S., and Quéguiner, B.: Pigments, elemental composition $(\mathrm{C}, \mathrm{N}, \mathrm{P}$, and $\mathrm{Si})$, and stoichiometry of particulate matter in the naturally iron fertilized region of Kerguelen in the Southern Ocean, Biogeosciences, 11, 5931-5955, doi:10.5194/bg-115931-2014, 2014.

Laurenceau, E. C., Trull, T. W., Davies, D. M., Bray, S. G., Doran, J., Planchon, F., Carlotti, F., Jouandet, M.-P., Cavagna, A.J., Waite, A. M., and Blain, S.: The relative importance of phytoplankton aggregates and zooplankton fecal pellets to carbon export: insights from free-drifting sediment trap deployments in naturally iron-fertilised waters near the Kerguelen plateau, Biogeosciences Discuss., 11, 13623-13673, doi:10.5194/bgd11-13623-2014, 2014.

Lee, C., Wakeham, S. G., and Hedges, J. I.: Composition and flux of particulate amino acids and chloropigments in equatorial Pacific seawater and sediments, Deep-Sea Res. Pt. I, 47, 1535-1568, 2000.

Le Quéré, C., Rodenbeck, C., Buitenhuis, E. T., Conway, T. J., Langenfelds, R., Gomez, A., Labuschagne, C., Ramonet, M., Nakazawa, T., Metzl, N., Gillett, N., and Heimann, M.: Saturation of the southern ocean $\mathrm{CO}_{2}$ sink due to recent climate change, Science, 316, 1735-1738, 2007.

Muller, P. J., Suess, E., and Ungerer, C. A.: Amino-acids and aminosugars of surface particulate and sediment trap material from waters of the Scotia Sea, Deep-Sea Res., 33, 819-838, 1986. 
Nagata, T., Meon, B., and Kirchman, D.: Microbial degradation of peptidoglycan in seawater, Limnol. Oceanogr., 48, 745-754, 2003.

Obernosterer, I., Christaki, U., Lefèvre, D., Catala, P., Van Wambeke, F., and Lebaron, P.: Rapid bacterial mineralization of organic carbon produced during a phytoplankton bloom induced by natural iron fertilization in the Southern Ocean, Deep-Sea Res. Pt. II, 55, 777-789, 2008.

Obernosterer, I., Fourquez, M., and Blain, S.: Fe and C co-limitation of heterotrophic bacteria in the naturally fertilized region off Kerguelen Islands, Biogeosciences Discuss., 11, 15733-15752, doi:10.5194/bgd-11-15733-2014, 2014.

Osterholz, H., Dittmar, T., and Niggemann, J.: Molecular evidence for rapid dissolved organic matter turnover in Arctic fjords, Mar. Chem., 160, 1-10, 2014.

Panagiotopoulos, C., Sempéré, R., Obernosterer, I., Striby, L., Goutx, M., Van Wambeke, F., Gautier, S., and Lafont, R.: Bacterial degradation of large particles in the southern Indian Ocean using in vitro incubation experiments, Org. Geochem., 33, 9851000, 2002.

Peter, S., Shen, Y., Kaiser, K., Benner, R., and Durisch-Kaiser, E.: Bioavailability and diagenetic state of dissolved organic matter in riparian groundwater, J. Geophys. Res., 117, G04006, doi:10.1029/2012JG002072, 2012.

Planchon, F., Ballas, D., Cavagna, A.-J., Bowie, A. R., Davies, D., Trull, T., Laurenceau, E., Van Der Merwe, P., and Dehairs, F.: Carbon export in the naturally iron-fertilized Kerguelen area of the Southern Ocean based on the ${ }^{234} \mathrm{Th}$ approach, Biogeosciences Discuss., 11, 15991-16032, doi:10.5194/bgd11-15991-2014, 2014.

Pomeroy, L., Williams, P., Azam, F., and Hobbie, J.: The Microbial Loop, Oceanogr., 20, 28-33, 2007.

Ras, J., Claustre, H., and Uitz, J.: Spatial variability of phytoplankton pigment distributions in the Subtropical South Pacific Ocean: comparison between in situ and predicted data, Biogeosciences, 5, 353-369, doi:10.5194/bg-5-353-2008, 2008.

Salter, I., Kemp, A., Lampitt, R., and Gledhill, M.: The association between biogenic and inorganic minerals and the amino acid composition of settling particles, Limnol. Oceanogr., 55, 22072218,2010 .
Sarmento, H., Romera-Castillo, C., Lindh, M., Pinhassi, J., Sala, M., Gasol, J., Marrase, C., and Taylor, G.: Phytoplankton species-specific release of dissolved free amino acids and their selective consumption by bacteria, Limnol. Oceanogr., 58, 1123 1135, 2013.

Sathyendranath, S., Stuart, V., Nair, A., Oka, K., Nakane, T., Bouman, H., Forget, M. H., Maass, H., and Platt, T.: Carbonto-chlorophyll ratio and growth rate of phytoplankton in the sea, Mar. Ecol.-Prog. Ser., 383, 73-84, 2009.

Savoye, N., Trull, T. W., Jacquet, S. H. M., Navez, J., and Dehairs, F.: ${ }^{234}$ Th-based export fluxes during a natural iron fertilization experiment in the Southern Ocean (KEOPS), Deep-Sea Res. Pt. II, 55, 841-855, 2008.

Shen, Y., Fichot, C. G., and Benner, R.: Dissolved organic matter composition and bioavailability reflect ecosystem productivity in the Western Arctic Ocean, Biogeosciences, 9, 4993-5005, doi:10.5194/bg-9-4993-2012, 2012.

Silver, M. W. and Gowing, M. M.: The "Particle"" Flux: Origins and biological components, Progr. Oceanogr., 26, 75-113, 1991.

Tremblay, L. and Benner, R.: Microbial contributions to Nimmobilization and organic matter preservation in decaying plant detritus, Geochim. Cosmochim. Ac., 70, 133-146, 2006.

Tremblay, L. and Benner, R.: Organic matter diagenesis and bacterial contributions to detrital carbon and nitrogen in the Amazon River system, Limnol. Oceanogr., 54, 681-691, 2009.

Van Heukelem, L. and Thomas, C. S.: Computer-assisted highperformance liquid chromatography method development with applications to the isolation and analysis of phytoplankton pigments, J. Chromatogr. A, 910, 31-49, 2001.

White, D. S. and Howes, B. L.: Nitrogen incorporation into decomposing litter of Spartina alterniflora, Limnol. Oceanogr., 39, 133 140, 1994.

Zubkov, M. V., Holland, R. J., Burkill, P. H., Croudace, I. W., and Warwick, P. E.: Microbial abundance, activity and iron uptake in vicinity of the Crozet Isles in November 2004-January 2005 Deep-Sea Res. Pt. II, 54, 2126-2137, 2007. 